\title{
DEMOCRACY, DISTRUST, AND JUDICIAL UMPIRING IN THE G-20 NATIONS
}

\section{Steven Gow Calabresi ${ }^{1}$}

John Hart Ely's book Democracy and Distrust: A Theory of Judicial Review (1980) is one of the most important books on constitutional theory written in the last sixty years. A central claim to Ely's book is that the courts ought to police the political processes of change to help political outsiders. No one who I am aware of has examined this claim critically or with reference to comparative constitutional law. Previous authors and book reviewers have just assumed that since the Warren Court's one person, one vote cases were correct, it must also be the case as Ely says in his book that courts should play a foundational role in umpiring the political process. This assumption is too facile since the U.S. Supreme Court has incorrectly decided at least three of the four major umpiring of the political process cases it has heard since 1980

The assumption is also too facile because Ely draws only on the American Experience, when today fifteen of the G-20 Nations are constitutional democracies with working systems of judicial review. I bring Ely up to date in this brief essay by discussing cases from the following nine G-20 Constitutional Democracies: 1) the United States since 1980;2) the United Kingdom; 3) Germany; 4) Japan; 5) India; 6) Canada; 7) Australia; 8) Brazil; and 9) South Africa. I should note that countries I study are on all six inhabited continents; include rich and poor nations; include common law and civil law nations; and represent the Global South as well as the Global North.

My first conclusion is that Ely is insufficiently skeptical of the

1. Clayton J. \& Henry R. Barber Professor, Northwestern University Pritzker School of Law. Copyright 2021-All rights reserved. This excerpt from a larger project is leased to Constitutional Commentary for the University of Illinois Symposium only and to the electronic publication of this essay on Westlaw, HeinOnLine, and other such electronic outlets. I want to retain here the right to use some of this material in my larger possibly book-length treatment of Democracy and Distrust 40 years after it was published. 
U.S. Supreme Court's actual practice in umpiring the political process. The Court gets wrong at least as many cases as it gets right. My second conclusion from studying the eight G-20 Nations listed above, along with the United States, is that they all umpire the political process to protect outsiders to at least some degree. This supports Ely's claim that courts do and should engage in umpiring of the political process while being more aware of the pitfalls of such a judicial role than they are. ${ }^{2}$

\section{THE UNITED STATES OF AMERICA}

Since Ely's book was published in 1980, there have been four key cases in which Ely would have called on the U.S. Supreme Court to protect the politically powerless. Ely's view lost, unjustly, in all three of the four cases, and most law professors would think that Ely was wrong about the fourth case as well. Ely just assumes that if a case is about umpiring the political process and not a substantive due process case, the Court will decide the case correctly. The following four post-1980 U.S. Supreme Court cases suggest Ely is way too optimistic here.

First, the U.S. Supreme Court decision in Shelby County v. Holder $^{3}$ is a classic umpiring of the political process case, in Professor Ely's terms. However, the political outsiders lost this case even though on the merits they should have easily won it. The issue was whether in renewing the Voting Rights Act of 1965 Congress ought to have revisited the data on which jurisdictions racially discriminate given the passage of forty-eight years to determine whether changes in their elections' laws should be subject to scrutiny and invalidation by the U.S. Department of Justice's Civil Rights Division (DOJ). The States argued that after forty-eight years of compliance with DOJ policy their election law changes should be made free of DOJ scrutiny. Congress and the President disagreed with the States involved and sought to retain DOJ preclearance of election law change from the covered States

2. I build here on my own work in 1 STEVEN GOW CALABRESI, THE HISTORY AND Growth of JUdicIAL REVIEW: THE G-20 COMMON LAW COUNTRIES AND ISRAEL (2021); and 2 STEVEn Gow CALABResi, THE History AND GROWTH OF Judicial REVIEW: THE G-20 CIVIL LAW COUNTRIES (2021). All of the cases discussed in this article appear edited and in English in STEVEN Gow CALABRESI, BRADLEY G. SILVERMAN \& JOSHUA BRAVER, THE U.S. CONSTITUTION AND COMPARATIVE CONSTITUTIONAL LAW: TEXTS, CASES, AND MATERIALS (2016) for anyone who wants to read them in fuller form. 3. 570 U.S. 529 (2013). 
and jurisdictions.

The original public meaning of Congress's Section 2 power to enforce the Fifteenth Amendment was understood by the Reconstruction Framers to be synonymous with the standard of review in McCulloch v. Maryland. ${ }^{4}$ Any law that was "convenient to" or "useful" to enhancing Black American's voting rights was presumptively constitutional, even if the Supreme Court could dream up in its head a better law that would better protect voting rights. The Justices in Shelby County complained that the States and jurisdictions covered by the Voting Rights Act (VRA) in 2013 were the exact same ones that were covered in 1965 when the VRA was passed. The Supreme Court in Shelby County said that Congress should update its forty-eight-year-old data on voter suppression clauses, since many jurisdictions that racially discriminated in 1965 were no longer doing so.

The States covered by the VRA in 2013 were: Alabama, Alaska, Arizona, Georgia, Louisiana, Mississippi, South Carolina, Texas, and Virginia. ${ }^{5}$ The ruling also affected some counties and townships in California, Florida, Michigan, New York, North Carolina, and South Dakota. ${ }^{6}$ The States covered by the 2013 preclearance review comprised ten of the eleven states that purported to secede from the Union during the Civil War. These States also all maintained vicious systems of racial apartheid until they were forced to dismantle them in the 1960s. While in an ideal world Congress should have updated its 1965 data on voter suppression, there is ample reason from American history to think that racism runs very deep in those formerly Confederate States. Given that Section 2 of the Fifteenth Amendment gives Congress sweeping powers to pass convenient or useful legislation to protect Black voting rights, Shelby County is egregiously wrong.

Chief Justice Roberts's opinion for the Supreme Court held quite rightly that there is an Equal Footing Doctrine, such that, in general, each State must be treated like every other State. The exception to this doctrine, however, comes from the clause in Article IV, Section 4, which says that "[t]he United States shall guarantee to every State in this Union a Republican Form of

4. 17 U.S. (4 Wheat) 316 (1819).

5. Jurisdictions Previously Covered by Section 5, DEP'T OF JUST., https://www.justice.gov/crt/jurisdictions-previously-covered-section-5.

6. Id. 
Government." In Texas v. White, ${ }^{7}$ the Supreme Court upheld the constitutionality of congressional Reconstruction whereby the eleven Confederate States were carved up into military districts, subjected to martial law, with a General of the Union Army in total command, so that a Republican Form of Government could be formed in them. The Confederate States were only allowed to re-enter the Union once Congress had: 1) approved of their new State constitutions enfranchising Black voters as being "Republican in form" and 2) once all eleven Confederate States had ratified the Fourteenth Amendment. The Equal Footing Doctrine obviously did not apply to Reconstruction and quite rightly so. The 1869 Supreme Court decision in Texas v. White is a longstanding, foundational Supreme Court precedent that limits the scope of the Equal Footing Doctrine.

From about the 1890s until the passage of the Voting Rights Act of 1965, Black Americans were systematically deprived of their constitutional right to vote. The NAACP estimates that only five million Blacks voted in the presidential election of $1960^{8}$ out of a total U.S. population of $179,323,175 .{ }^{9}$ There were $26,898,476$ Black Americans in $1960 .{ }^{10}$ It is obvious from these numbers that the vast majority of Black Americans were disenfranchised in the 1960 presidential election, which is why the Voting Rights Act of 1965 was passed. It is also evident from extensive congressional hearings that most of this voting rights discrimination against Black Americans was occurring in the eleven former Confederate states.

A Republican Form of Government is one in which all citizens can vote easily. Congress had the authority to require preclearance review by the Justice Department in the formerly Confederate States because they were still violating the Guarantee Clause one hundred years after the Civil War, and they were now violating the Fifteenth Amendment as well, by denying Black Americans the right to vote. The Equal Footing Doctrine, which is a real doctrine, did not apply to the First Reconstruction of the South in the 1860s, and it obviously does

7. 74 U.S. (7 Wall.) 700 (1869).

8. Cabell Phillips, U.S. Negro Voters Put at 5.5 Million, N.Y. TIMES, Oct. 13, 1964, at 24, https://www.nytimes.com/1964/10/13/archives/us-negro-voters-put-at-55million.html.

9. U.S. Census Bureau, 1960 Census of Population: General Population CHARACTERISTICS 4 (1961)

10. Id. 
not apply to the Second Reconstruction of the South in the 1960s. It is up to Congress not the Supreme Court to decide when the Second Reconstruction should end. This is made clear by Luther $\mathrm{v}$. Borden,${ }^{11}$ which suggested in dicta that the political branches of the federal government had exclusive power over Guarantee Clause cases. Shelby County v. Holder is a major blunder by the Supreme Court that calls Ely's argument that courts ought to be umpires of the political process into question.

Another major blunder the Supreme Court has made in umpiring the political process was its year 2000 decision to settle a presidential election in Bush v. Gore. ${ }^{12}$ My own disagreement with Bush v. Gore has been published elsewhere, ${ }^{13}$ and there is no need to repeat here what I said there. The umpiring of the political process in Bush v. Gore sapped the Supreme Court's legitimacy and President George W. Bush's legitimacy in a way that makes one think that courts are not, contra Ely, ideal, neutral umpires of the political process. Strikingly, the Supreme Court, inferior federal courts, and the state courts all went out of their way unanimously to avoid umpiring the hotly contested 2020 presidential election between Joseph R. Biden and Donald J. Trump. Perhaps, the Supreme Court and other courts felt burned by the pushback they encountered in Bush v. Gore.

A third judicial umpiring case that has arisen since the publication of Democracy and Distrust in 1980 was Rucho v. Common Cause, ${ }^{14}$ a case in which a five to four majority of the Supreme Court held that cases challenging the gerrymandering of state congressional and state legislative districts were always nonjusticiable political questions. In Baker v. Carr, ${ }^{15}$ Justice William J. Brennan Jr. held that the one person, one vote cases were justiciable over a heated dissent from Justice Felix Frankfurter that they would land the Supreme Court in a political thicket. In Rucho v. Common Cause, Chief Justice John Roberts essentially wrote Justice Frankfurter's dissent into the governing caselaw of the Supreme Court in gerrymandering cases.

Chief Justice Roberts' opinions in Rucho v. Common Cause

11. 48 U.S. (7 How.) 1 (1849).

12. 531 U.S. 98 (2000).

13. Steven G. Calabresi, A Political Question, in Bush v. Gore: The QUestion of LEGITIMACY 129 (Bruce Ackerman ed., 2002).

14. 139 S. Ct. 2484 (2019).

15. 369 U.S. $186(1962)$ 
and in Shelby County v. Holder conflict. The Chief Justice holds that the Voting Rights Act of 1965, a super statute, passed by Congress and signed by the president is unconstitutional, but Chief Roberts also denies that the Supreme Court has any power at all to decide gerrymandering cases. This is a very odd way in which to judicially review cases involving outsiders' access to the political process. The key difference for Chief Justice Roberts seems to be that the rule of "one person, one vote" is easily administrable and does not draw the federal courts into a political thicket. Robert sees no such bright line rule when it comes to redistricting, and he thus rejects a role that he fears would politicize the federal courts the way Bush v. Gore did.

Chief Justice Roberts' concern about keeping the courts out of politics and avoiding a series of Bush v. Gores is laudable, but I think it is inconsistent with his judicially activist opinions in Shelby County v. Holder and in Rucho v. Common Cause. Roberts claims the one person, one vote cases were constitutional because they laid out an easy rule to apply, but he denies that any such rule exists as to political gerrymandering cases. This is simply not true. The Federal Apportionment Act of 1911 required that congressional districts should be as compact and as nearly equal in population as possible. ${ }^{16}$ This statutory requirement was for some reason repealed by the Federal Reapportionment Act of $1929 .{ }^{17}$ Nevertheless, it seems very clear to me that the Supreme Court is perfectly capable of policing a compactness requirement, as well as the one person, one vote requirement, invalidating only the most egregious gerrymanders. Districts are either full of squiggly lines, like the original gerrymander cartoon (Fig. 1), or legislative districts are neat and compact like Iowa's current congressional districts (Fig. 2).

16. Apportionment Act of 1911, Pub. L. No. 62-5, § 3, 37 Stat. 13

17. Reapportionment Act of 1929, Pub. L. No. 71-13, 46 Stat. 21. 


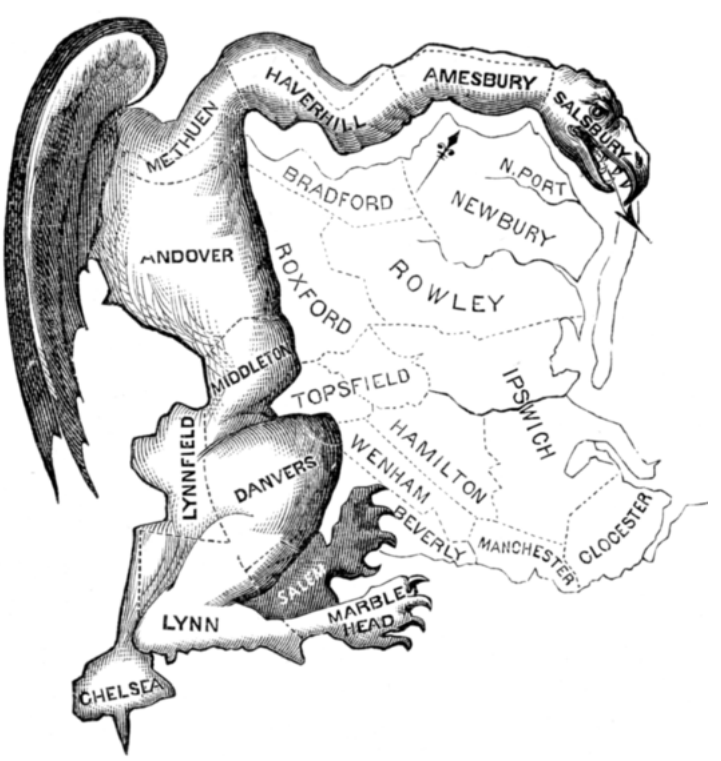

Figure 1. The Gerry-mander. ${ }^{18}$

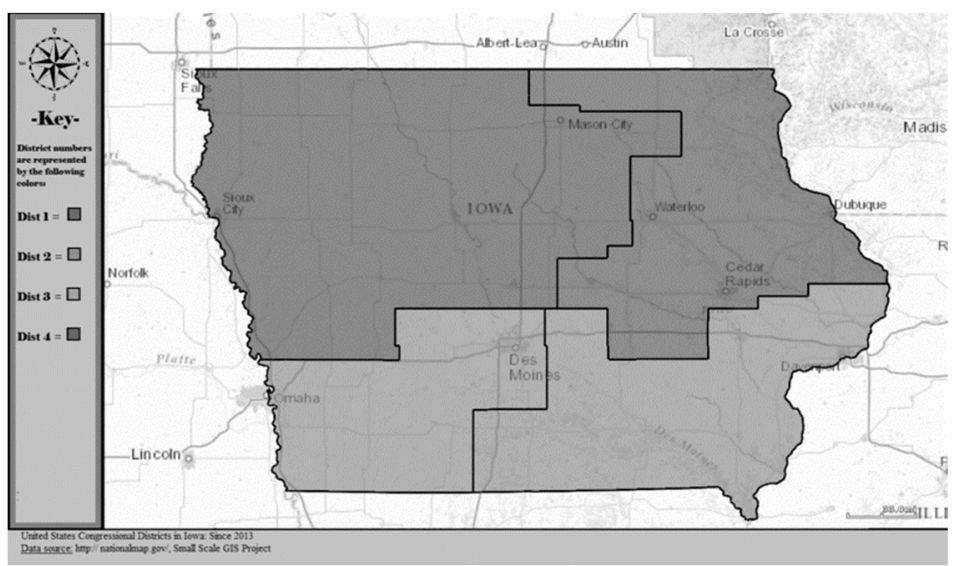

Figure 2. United States Congressional Districts in Iowa, since 2013. ${ }^{19}$

It doesn't take a rocket scientist to differentiate between the gerrymandered district and Iowa's compact congressional

18. Elkanah Tisdale, The Gerry-mander, BOS. GAZETTE, Mar. 26, 1812, at 2, https://en.wikipedia.org/wiki/File:The_Gerry-Mander_Edit.png.

19. US Department of the Interior, public data retrieved from http://cdmaps.polisci.ucla.edu on October 18, 2014, https://commons.wikimedia.org/wiki/ File:United_States_Congressional_Districts_in_Iowa,_since_2013.tif. 
districts, which is why Congress required from 1911 to 1929 that congressional districts be as nearly equal in population and compact as possible.

In fact, the one person, one vote decisions greatly increased State legislative power to gerrymander because they freed the States from the political need to follow municipal and county boundary lines in doing redistricting. The gerrymandering crisis, which the United States has today, is a side effect of the laudable Supreme Court one person, one vote decisions, which the Supreme Court issued in the 1960s.

American democracy is plagued by sky-high reelection rates for members of Congress, which date back to the publication in 1980 of Democracy and Distrust and which are largely the result of gerrymandering. Consider the following chart of congressional House members' reelection rates over the last forty years: 
Table 1: Reelection Rates for House Members ${ }^{20}$

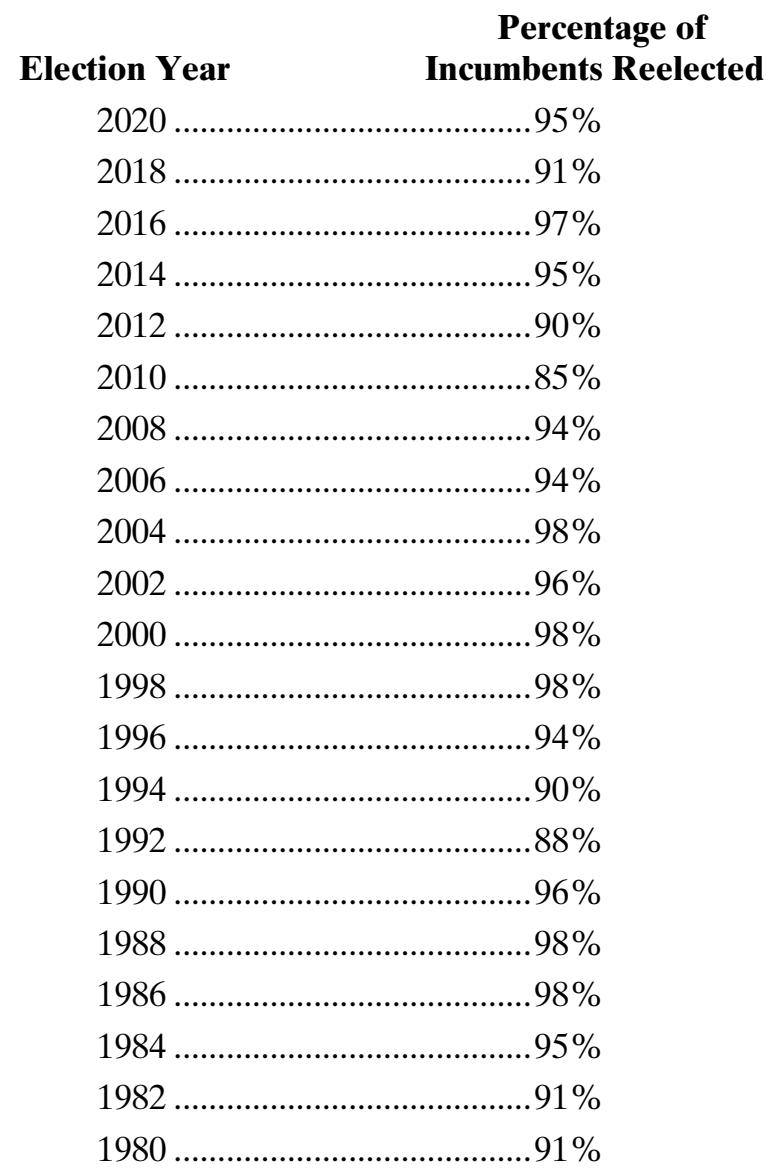

The U.S. House of Representatives reelection rate in the forty years since Ely's book was published only twice dips below $90 \%$, and it has been as high as $98 \%$ in several elections. Democratic theorists and Constitutional scholars should be "shocked" by these numbers. In 1937, Joseph Stalin held the first elections for the Supreme Soviet of the Soviet Union of Socialist Republics, and the Communist Party candidates received 99.3\% of the vote. ${ }^{21}$ Stalin also held elections for the upper House called

20. Tom Murse, Do Members of Congress Ever Lose Re-Election?, THOUghtCo. (Dec. 10, 2020), https://www.thoughtco.com/do-congressmen-ever-lose-re-election3367511.

21. Dieter Nohlen \& Philip Stover, Elections in Europe: A DatA 
the Soviet of Nationalities, and the Communist Party candidates received $99.4 \%$ of the vote in those elections. ${ }^{22}$ U.S. congressional elections for the House of Representatives are not much more competitive than were elections for the Communist totalitarian government of the Soviet Union.

Forty percent of congressmen and women are from safely Republican districts, forty percent are from safely Democratic districts, and only twenty percent represent true swing seats that either party could win. What this means is that the only way a safe Republican can lose is in a primary to a more conservative foe, so Republicans in safe districts tack to the right to head off primary challenges. Similarly, the only way a safe Democrat can lose is in a primary to a more progressive foe, so Democrats in safe districts tack to the left to head off primary challenges. As a result, the House of Representatives has become much more bitterly partisan and divided than it has ever been in American history since the 1850 s and 1860 s with catastrophic results like those on display during the January 6, 2021 riot after the 2020 presidential election in the Capitol Building.

Since the U.S. Supreme Court has gone AWOL in the gerrymandering crisis, Congress should pass a simple bill under Article I, Section 4 restoring the language that was in federal law from 1911 to 1929: "Congress shall be elected by districts composed of a contiguous and compact territory, and containing as nearly as practicable an equal number of inhabitants." ${ }^{23}$ The Apportionment Act of 1911 was right, and the Reapportionment Act of 1929 was wrong. Congressional districts should be compact.

A fourth access to the political process case decided since 1980, which I agree with is Citizens United v. FEC. ${ }^{24}$ In this five to four case, the Supreme Court correctly struck down several federal campaign finace laws on freedom of speech and of the press grounds. These laws were also, in my view, blatant incumbent protection statutes. Ely himself in Democracy and Distrust mentions campaign finance laws as being constitutionally suspect incumbent protection measures. I mention Citizens United v. FEC, along with Shelby Country v. Holder, Bush v.

HANDBOOK 1642 (2010)

22. $I d$.

23. Apportionment Act of 1911, Pub. L. No. 62-5, § 3, 37 Stat. 13.

24. 558 U.S. 310 (2010). 
Gore and Rucho v. Common Cause only because the $98 \%$ of my audience who are law professors think that all four of these cases were egregiously and wrongly decided. What this shows is that the Supreme Court is just as political and activist in deciding "access of outsiders to the political process" cases as Ely correctly faults it for being in "substantive due process" cases. For better or worse, the Supreme Court is an elite, oligarchic feature of our constitution, which in Ely's day followed the views of the leftist elite, but which, since Bush v. Gore in 2000, has followed the views of rightist elites.

\section{THE UNITED KINGDOM OF GREAT BRITAIN AND NORTHERN IRELAND}

The Supreme Court of the United Kingdom has decided two vital umpiring cases in the last four years - both cases in which political outsiders had their rights violated, and the Supreme Court of the United Kingdom came to their rescue.

In the first case, $\mathrm{R}$ (Miller) v. Secretary of State for Exiting the European Union, ${ }^{25}$ the question was whether Her Majesty, Queen Elizabeth II could use her royal prerogative powers to revoke the forty or so treaties by which the United Kingdom had joined the European Union. Traditionally, English Monarchs had always had the power to make or revoke treaties unilaterally. In the United States, the President does have the unilateral authority to revoke treaties. President Washington unilaterally revoked the treaty allying the U.S. with France from 1778 with his Neutrality Proclamation of $1793 .{ }^{26}$ In more recent times, both Presidents George W. Bush and Donald J. Trump have unilaterally revoked arms control treaties. ${ }^{27}$

Prime Minister Theresa May's government was of the view that she and the executive government could on their own effectuate Brexit by asking the Queen to effectuate Brexit using

25. [2017] UKSC 5 (Miller I).

26. George Washington, Proclamation of Neutrality (1793), reprinted in 32 THE Writings OF GEORGE WASHINGTON FROM THE ORIGINAL MANUSCRIPT SOURCES 1745-1799, at 430, 430-31 (John C. Fitzpatrick ed., 1939).

27. Terence Neilan, Bush Pulls Out of ABM Treaty; Putin Calls Move a Mistake, N.Y. TIMES (Dec. 13, 2001), https://www.nytimes.com/2001/12/13/international/bush-pulls-outof-abm-treaty-putin-calls-move-a-mistake.html; Bill Chappell, Trump Moves to Withdraw U.S. from U.N. Arms Trade Treaty, NPR (Apr. 26, 2019), https://www.npr.org/2019/04/26/717547741/trump-moves-to-withdraw-u-s-from-u-n-armstrade-treaty. 
the royal prerogative. Since 1911, U.K. kings and queens have scrupulously exercised the royal prerogative only in the way that the Prime Minister asks them to do. The Monarch's role is totally ceremonial. Queen Elizabeth II would have revoked or retained U.K. membership in the European Union totally at the discretion of the Prime Minister in charge of the U.K. government at any time.

Prime Minister May also thought that since the British people had voted for Brexit in a referendum by a margin of $51.9 \%$ to $48.11 \%{ }^{28}$ that the referendum as well gave her executive cabinet the power to effectuate Brexit without an additional vote in Parliament. The Supreme Court of the United Kingdom held that Brexit was so intertwined with statutes that only Parliament, which is sovereign could effectuate Brexit. The Court also politely implied that the Queen's unilateral power to revoke treaties had lapsed into desuetude. The implication was polite because Queen Elizabeth II is revered by the people of the United Kingdom.

The Court was equally unimpressed with Prime Minister May's argument that the Brexit referendum gave the Cabinet power to effectuate Brexit. The Court said that in the United Kingdom only the Queen in Parliament with the House of Lords and the House of Commons could effectuate Brexit because that is where sovereignty lies and has always lain. The people of the United Kingdom are not sovereign, but the Queen-in-Parliament is. The outcome was a stunning slap down by the U.K. Supreme Court of both the Queen and the Prime Minister and of the referendum process. In the end, Parliament voted for Brexit feeling itself obliged to do so because of the outcome of the referendum.

The second federalism and separation of powers umpiring case to be decided by the U.K. Supreme Court in 2019 was, if anything, even bolder and more aggressive than was the first. The issue in R (on the application of Miller) v. The Prime Minister and Cherry v. Advocate General for Scotland ${ }^{29}$ was the legality of Conservative Prime Minister Boris Johnson's request that Queen Elizabeth II prorogue, that is end, a session of parliament between September 9 and 12 and October 14, 2019, allegedly to prevent

\footnotetext{
28. EU Referendum, BBC, https://www.bbc.co.uk/news/politics/eu_referendum/ results.

29. [2019] UKSC 41 (Miller II).
} 
Parliament from continuing to debate Brexit and attack the Prime Minister. On August 28, 2019, "[a]n Order in Council was made ordering that the Parliament be prorogued [between those dates]' and that the Lord Chancellor 'do cause a Commission to be prepared and issued in the usual manner for proroguing the Parliament accordingly." 30 Prime Minister Johnson informed Queen Elizabeth II that his government wanted to prorogue Parliament, and the Queen rightly followed the desires of the government in executive office.

The High Court of England and Wales upheld the legality of the prorogation, but the Inner House of the Court of Session in Scotland held that the prorogation was unlawful. Both cases were appealed to, and were heard together, by the Supreme Court of the United Kingdom. All eleven members of the U.K. Supreme Court, a full bench, heard the cases, and the Court held unanimously that the prorogation was unlawful thus affirming the Scottish decision while reversing the High Court of England and Wales. The decision did not discuss the merits of Brexit, but it did decide the executive power question of whether the royal prerogative still allowed prorogation in 2019, and whether the matter raised a political question such that it was not justiciable. The U.K. Supreme Court said that the case was justiciable citing a 1611 opinion $^{31}$ in which Sir Edward Coke overturned a decision of King James I also cited in the Miller I case.

The Court said that the two fundamental principles of the unwritten British Constitution, which were at stake here were: 1) parliamentary sovereignty, which required that there be time to debate and enact laws; and 2) the accountability of Prime Minister Johnson and his government to questioning in the House of Commons. The U.K. Supreme Court held that "[t]his was not a normal prorogation in the run-up to a Queen's Speech. It prevented Parliament from carrying out its constitutional role for five out of a possible eight weeks between the end of the summer recess and exit day [which was then] on the 31st October [for the U.K. to leave the European Union.]"32

The Court held that this prolonged suspension of Parliamentary democracy had an "extreme" effect "upon the

\footnotetext{
30. Id. at 6 .

31. Case of Proclamations (1611) 77 Eng. Rep. 1352.

32. [2019] UKSC 41, at 20.
} 
fundamentals of our democracy." 33 Under these circumstances, the U.K. Supreme Court was "bound to conclude, therefore, that the decision to advise Her Majesty to prorogue Parliament was unlawful because it had the effect of frustrating or preventing the ability of Parliament to carry out its constitutional functions without reasonable justification." 34 As a result, "the Prime Minister's advice to Her Majesty was unlawful, void and of no effect. This means that the Order in Council to which it led was also unlawful, void and of no effect and should be quashed. This means that when the Royal Commissioners walked into the House of Lords it was as if they walked in with a blank sheet of paper. The prorogation was also void and of no effect. Parliament has not been prorogued." 35

The Miller II case was an extraordinary assertion of judicial power, which calls to mind Marbury v. Madison in 1803. These two very recent U.K. Supreme Court cases reveal the ubiquity in constitutional democracies of cases in which Supreme Courts are asked to intervene and do intervene to protect the political process. The U.K. Supreme Court engaged in Elyan judicial review quite sensibly in these two cases. U.K. judicial review is important because all of the world's democracies today descend from the U.S. democracy, which was critically shaped by the unwritten constitution of the United Kingdom. The U.K. was a cricial U.S. ally in World Wars I and II, and during the Cold War, and the U.K. today has the sixth largest economy in the world. ${ }^{36}$ Anything that happens in the U.K. is globally relevant given the Commmonwealth of Nations with its fifty-four member nations, all of which were once part of the British Empire. At its height, the British Empire included one quarter of the world and the sun never set on its territorial possessions.

\section{THE FEDERAL REPUBLIC OF GERMANY}

German judicial review dates back to the adoption by West Germany in 1949 of the Basic Law, which has become Germany's constitution. I should say at the outset that German judicial

33. Id. at 21 386

34. CALABRESI, THE G-20 COMMON LAW COUNTRIES AND ISRAEL, supra note 2, at

35. Id.

36. Caleb Silver, The Top 25 Economies in the World, INVESTOPEDIA (Dec. 24 2020), https:/www.investopedia.com/insights/worlds-top-economies/. 
review has had a huge impact on all the Civil Law countries of the world. Since two-thirds of the countries in the world are Civil Law nations, German judicial review is coequal in importance with U.S. judicial review in spreading the idea of the desirability of a powerful Constitutional Court all over the world as of 2021. The definitive work in English on German Constitutional Law is Donald Kommers and Russell Miller's treatise on this subject, ${ }^{37}$ which I rely upon throughout this section of my essay.

Germany differs from the U.S. and the U.K. in that it has a constitutional court, which is a fourth branch of government, and which is the only court or entity in Germany that can rule on constitutional cases. The idea for such a court originated with Professor Hans Kelson, who devised similar courts in the 1920s in the then countries of Czechoslovakia and Austria. Professor Kelson was well aware that civil law countries reflexively opposed judicial review because of the traditional French Revolutionary fear of gouvernement des juges. Kelson's response was to create a fourth branch of government-outside of the legislature, the executive, and the judiciary, which would have the sole power of judicial review. Members of this Court serve for fixed, staggered terms, and are sometimes subject to a mandatory retirement age. They are appointed by a special high level appointment process to attract brilliant and prestigious judges. Their decisions are binding precedents on all executive and judicial officers. Their differing natures are described in more detail in the materal cited in the footnote to this sentence. ${ }^{38}$

The German Constitutional Court decided a case very much like the U.S. one person, one vote cases in Electoral District II. ${ }^{39}$ The lower house of the German legislature is elected with one quarter of the members being picked from territorial districts and three-quarters by proportional representation from party lists with a $5 \%$ threshold. In the Electoral District II case, the Court heard a challenge to the constitutionality of the 1961 federal election in which Schleswig-Holstein had more districts than would be warranted under a rule of one person, one vote. As the

37. Donald P. Kommers \& Russell A. Miller, The Constitutional JURISPRUDENCE OF THE FEDERAL REPUBLIC OF GERMANY (3d ed. 2012).

38. The differing roles of common law Supreme Courts and of Civil Law Constitutional Courts is described in CALABRESI ET AL., THE U.S. CONSTITUTION AND COMPARATIVE CONSTITUTIONAL LAW, supra note 2 at 291-308.

39. 16 BVerfGE 130 (1963). 
Court said:

districts with approximately equal population figures must be created when it is technically possible so that no state will end up with more districts than its ... share of the total population in the federal territory would warrant. If all districts are of approximately the same size, then their approximate distribution among the states will be guaranteed, thus keeping the number of excessive mandates at a constitutionally permissible minimum. ${ }^{40}$

Germany, in effect, has its own one person, one vote rule. This case thus prevents political insiders from manipulating the population of the territorial districts from political interference by political insiders trying to keep challengers out. Since Germany has eighty-three million people,${ }^{41}$ the fourth largest economy in the world, ${ }^{42}$ and is the powerhorse engine that drives the economy of the twenty-seven-member nation European Union, the presence of a one person, one vote rule in Germany identical to the one in the United States suggests the ubiquity of the phenomenon Ely was describing in Democracy and Distrust.

\section{JAPAN}

The Constitution of Japan went into effect on May 3, 1947, and it sets up a Western-style liberal democratic regime based on the sovereignty of We the People of Japan. The Japanese Constitution is the oldest constitution in Asia, and it is older than the Basic Law, as well. The Japanese Constitution explicitly gives the Japanese Courts American-style diffuse powers of judicial review. The Constitution has never been amended because amendments must pass both Houses of Parliament by a two-thirds majority and then be ratified by $51 \%$ of the people in a national election. The governing reactionary and nationalist Liberal Democratic Party has wanted, for example, to get rid of the Japanese Constitution's protection of freedom of expression, but polls show that a healthy majority of the Japanese people like the

40. Calabresi, et Al., The U.S. Constitution And Comparative CONSTITUTIONAL LAW, supra note 2, at 1623.

41. Population Estimates and Projections, WORLD BANK, https://datacatalog.worldbank.org/dataset/population-estimates-and-projections (select

"Database Access," then choose Germany under "Country," total population under "Series," and 2021 under "Time")

42. Silver, supra note 36. 
Constitution as it is now and do not want to see it amended. ${ }^{43}$ Thus, even though U.S. General Douglas MacArthur's staff wrote portions of the Constitution, ${ }^{44}$ the document is revered and cherished by the people of Japan. There is no legitimacy problem with the Constitution of Japan.

The Japanese elite leaders of the Liberal Democratic Party have long yearned to draft their own constitution, which reflects their extremely conservative attitudes. Former Prime Minister Shinzo Abe, for example, wanted to delete the freedom of expression clause in Japan's constitution as well as deleting the clause that says that Japan's Emperor is under, and not above, the Constitution. ${ }^{45}$ As Professor David S. Law has pointed out, however, in his book chapter on Japan, The Myth of the Imposed Constitution, the people of Japan revere the Constitution and will vote down any effort to change it. Since the Constitution of Japan can only be amended by a two-thirds vote of both houses of the legislature and a vote of $51 \%$ in favor of a constitutional amendment in a national referendum, no government of Japan has ever sought to pass a constitutional amendment, and the 1947 Constitution has never been amended. ${ }^{46}$

The Supreme Court of Japan has been described by Professor Law as being the most "conservative constitutional court in the world" in that it is "so passive or cautious that it almost never challenges the government." ${ }^{47}$ Professor Law notes that since the Court's creation in 1947, it "has struck down only eight statutes on constitutional grounds. By way of comparison, Germany's constitutional court, which was established several [years after Japan's], has struck down over 600 laws." ${ }^{48}$ For an explanation as to why the effort to transplant judicial review from

43. Public Attitudes on Revision: Media Polling Since 2000, COUNCIL ON FOREIGN RELS., https://www.cfr.org/japan-constitution/public-attitudes-on-revision.

44. Shigenori Matsui, Why is the Japanese Court So Conservative?, 88 WASH. U. L. REV. 1375, 1376 (2011).

45. Linda Sieg, Japan PM's 'Stealth' Constitution Plan Raises Civil Rights Fears, REUTERS (May 1, 2013), https://www.reuters.com/article/us-japan-politics-constitutionidUSBRE94101D20130502.

46. David S. Law, The Myth of the Imposed Constitution, in SocIAL AND POLITICAL Foundations of CONSTITUTIONS 239, 239-68 (Denis J. Galligann \& Mila Versteeg eds, 2013).

47. David S. Law, The Anatomy of a Conservative Court: Judicial Review in Japan, 87 TEX. L. REV. 1545 (2009)

48. Id. at 1547 . 
the U.S. to Japan failed, see the source cited in this footnote. ${ }^{49}$

The Japanese Supreme Court's most important decision of all time is a one person, one vote case modelled on the U.S. caselaw. In Kurokawa v. Chiba Prefecture Election Commission, ${ }^{50}$ the Supreme Court of Japan concluded that Japan's malapportionment of electoral districts and failure to update electoral district line was unconstitutional. Chiba is Japan's endorsement of the one person, one vote idea although the Court does not go so far as to adopt such a rule in Japan. The Court acknowledges that some deviation from one person, one vote may serve other legitimate goals. It concludes, however, that:

At the time of the 1972 election for the House of Representatives ... the actual discrepancy in voters represented by individual Diet members had grown to a maximum of 5 to 1 . Such a deviation violates the constitutional requirement for equality in the right to vote. The cause of deviations can be attributed mainly to shifts in population.... Reapportionments based on changes in population should be carried out within a reasonable period of time; and when the Diet does not do so, it violates the Constitution.

In Chiba, there had been no revision for more than eight years, after the 1964 appointment in spite of the fact that the Public Office Election Law requires reapportionment of the Diet every five years, based on the most recent national census. Thus the actual appointment of seats at the time of the election violated the constitutional requirement of equality of voting rights. ${ }^{51}$

The holding in Chiba set off a massive battle between the Supreme Court of Japan, which wanted something closer to one person, one vote, and the governing Liberal Democratic Party, which wanted more rural conservative districts. As of 2021, the Supreme Court of Japan has gotten the discrepancy in voters represented by individual Diet members down from five to one to a number that is roughly three to one. The Supreme Court has had an Elyan impact on malapportionment, but the government has successfully avoided full compliance with the

49. CAlabresi, THE G-20 Civil LAW COUNTRIES, supra note 2, at 115-31.

50. Saikō Saibansho [Sup. Ct.] Apr. 4, 1976, 30 SAIKŌ SAIBANSHO MINJI HANREISHŪ [MINSHŪ] 223.

51. Calabresi et Al., THE U.S. CONSTITUTION AND COMPARATIVE CONSTITUTIONAL LAW, supra note 2, at 1626-27. 
Chiba Court's ruling.

Japan has the oldest Constituiton of any nation in Asia, it has a population of 125 million people, ${ }^{52}$ and it has the third largest economy in the world ${ }^{53}$ after only the United States, and China, which has immensely more people than Japan. The fact that Japan, like Germany, has endorsed the Warren Court's one person, one vote rule in its most important decision of all time confirms the centrality of Ely's insight that courts must police the processes of political change.

\section{THE REPUBLIC OF INDIA}

India is by far and away the most populous democracy and jurisdiction in the world with judicial review of the constitutionality of legislation. It has twenty-eight states and eight union territories. India has the most powerful and activist Supreme Court of any nation in the world. The Supreme Court of India not only allows citizen standing; it also takes jurisdiction over letters to the editor of a newspaper. The Justices of the Court have assumed the power to appoint new members of the Supreme Court making that court a self-perpetuating body like a law school faculty. Finally, the Supreme Court of India has successfully claimed the power to hold new amendments to the Constitution of India unconstitutional.

The foundational case in which the Indian Supreme Court acted to help the historically disadvantaged and politically powerless is M.C. Mehta and Anr. v. Union of India \& Ors. ${ }^{54}$ This is the case which essentially abolished standing in the Indian Supreme Court so that a letter to a Justice, or even a letter to the editor of a newspaper, can trigger the Supreme Court's power of judicial review. It is this case, more than any other, that allows political outsiders in India to challenge political insiders, which is a key function for courts according to Ely. The Indian Supreme Court has acted vigorously to promote better health care and education and other government entitlements for the poor. It has even assumed the power, which the text of the Constitution denies

52. Population Estimates and Projections, WORLD BANK, https:/datacatalog.worldbank.org/dataset/population-estimates-and-projections (select "Database Access," then choose Japan under "Country," total population under "Series," and 2021 under "Time").

53. Silver, supra note 36.

54. 1987 AIR (1086); 1987 SCR (1) 819. 
to it, of enforcing the Directive Principals as well as the Bill of Rights.

The leading case in India in which the Supreme Court of India has engaged in umpiring of the political process to protect minority parties and political outsiders is S.R. Bommai v. Union of India. ${ }^{55}$ This case addressed a practice that had grown up between 1950 and 1994 whereby Presidents of India used their "emergency powers" to dissolve a state government and provide for presidential rule in that state. Although this power was supposed to be used only in dire emergencies, India's prime ministers had developed a bad habit of routinely dissolving state governments whenever the opposite political party diverged from the one dominant nationally for purely partisan reasons. This totally undermined federalism in India, which is especially problematic in such a populous country, with so many different ethnic groups and with so many different language groups. As a result, between 1950 and 1994, Presidents of India, following a prime minister's orders, had dissolved a state government on 95 occasions $!^{56}$ The Supreme Court of India declared that this was an unconstitutional abuse of the emergency power, and the Court issued strict guidelines as to the kinds of situations in which Presidents of India could declare emergency rule in a state consistently with the Constitution. The Supreme Court's opinion stopped the abuse of presidential rule in states controlled by political outsiders at the national level.

These two cases from India, the most populous democracy in the world, and the fifth largest economy in the world, ${ }^{57}$ confirm again the importance of John Hart Ely's claim in Democracy and Distrust that a central role for courts engaging in judicial review is umpiring the processes of political change to keep them open to political outsiders.

\section{CANADA}

Our next-door neighbor Canada has a vibrant and very active system of what it calls second look judicial review. The Canadian

55. (1994) 2 S.C.R. 664 (India). 292

56. CALABRESI, THE G-20 COMMON LAW COUNTRIES AND ISRAEL, supra note 2, at

57. Silver, supra note 36 . 
federation evolved from being, in 1867, a mere Dominion of the British Empire, with no foreign policy or defense powers, and subject to British law, into being an independent nation state affiliated with, and coequal to, the U.K. as of 1931. By passing the Statute of Westminster, $1931,{ }^{58}$ the British Empire freed all of its self-governing Dominions in Canada, Australia, New Zealand, and South Africa. It also repealed ${ }^{59}$ the Colonial Laws Validity Act, 1865, which had made British laws applicable throughout the British Empire. ${ }^{60}$ The Statute of Westminster gave the Dominions the power to end appeals from their highest courts to the Judicial Committee of the Privy Council (JCPC), the highest court in the British Empire, and, in 1949, Canada ended all appeals to the JCPC. ${ }^{61}$ The Statute of Westminster, 1931, marked the true beginning of Canada's existence as an independent nation. Canada has not yet severed its ties with the U.K.'s Monarch, and Queen Elizabeth II is Queen of Canada. Her power is exercised by a Canadian Governor General picked by the Prime Minister of Canada.

Canada today is a parliamentary democracy with a Prime Minister who is picked by and can be unseated at any time by the Canadian House of Commons. Canada has an appointive Senate with little power. There are today ten Canadian Provinces and three territories. Prime Minister Pierre Elliot Trudeau, the father of Canada's current Prime Minister, Justin Trudeau, is also the founding father of modern Canada. His biggest legacy is a statute passed by the U.K. Parliament in 1982 called the Canadian Constitution Act, $1982 .{ }^{62}$ This statute did four things. First, it gave Canada a Bill of Rights called the Canadian Charter of Rights and Freedoms, which establishes a second look system of judicial review. Second, the U.K. Parliament enacted an amending power to the British North America Act, so that since 1982 Canada has been able to amend its own Constitution without asking for a statute from London. Third, the U.K. Parliament renounced any power to legislate for Canada ever again in the future. And, fourth, the U.K. Parliament renamed the British North America Act, 1867 to be "The Canadian North America Act, 1867."

58. Statute of Westminster, 1931, 22 \& 23 Geo. 5, c. 4 (U.K.).

59. Id. § 2(1).

60. Colonial Laws Validity Act, 1865, 28 \& 29 Vict. c. 63 (U.K.). 185

61. CALABRESI, THE G-20 COMMON LAW COUNTRIES AND ISRAEL, supra note 2 , at

62. Constitution Act, 1982, being Schedule sB to the Canada Act, 1982, c 11 (U.K.). 
Canadian judicial review under the Charter of Rights and Freedoms is called second look judicial review for two reasons. First, Section 1 of the Charter says that:

1. The Canadian Charter of Rights and Freedoms guarantees the rights and freedoms set out in it subject only to such reasonable limits prescribed by law as can be demonstrably justified in a free and democratic society. ${ }^{63}$

What this means in practice is that Parliament can pass laws that violate explicit Charter provisions, so long as it does so "reasonably" and in a way that can be "justified in a free and democratic society." Moreover, Section 33 of the Charter allows Canadian provincial or national governments to suspend the operation of any Supreme Court opinion for five years. ${ }^{64}$ At the end of that time a Province can suspend the Canadian Supreme Court opinion for another five years, but this has never happened. So far, Section 33 has been used 20 times by the provinces and never by the national government, and it is on its way toward becoming as obsolete as is the Queen's veto power in Great Britain. ${ }^{65}$ The Canadian Supreme Court has issued several decisions, which protect politically powerless outsiders while umpiring the political process.

In Ford v. Quebec (Attorney General) ${ }^{66}$ the Province of Quebec had passed a law, which forbade shopkeepers from displaying their stores names using English rather than French words. Quebec was concerned that some cities like Montreal, with a large English-speaking minority, were losing their "visages linguistic" and French language and culture was thus disappearing in Quebec Province itself. Ford, an English-speaking Canadian, operating a shop that sold wool wanted the English word "wool" to appear outside her shop. The Attorney General of Quebec brought a case against her under the new Quebec law, and she defended herself by invoking Section 2.b of the Canadian Charter of Rights and Freedoms, which protects freedom of expression. ${ }^{67}$

63. Canadian Charter of Rights and Freedoms, Part I of the Constitution Act, 1982, being Schedule B to the Canada Act, 1982, c $11 \S 1$ (U.K.).

64. Id. §33.

65. CALABRESI, THE G-20 COMMON LAW COUNTRIES AND ISRAEL, supra note 2, at 203.

66. [1988] 2 S.C.R. 712 (Can.)

67. Canadian Charter of Rights and Freedoms, Part I of the Constitution Act, 1982, being Schedule B to the Canada Act, 1982, c 11 § 2(b) (U.K.) ("Everyone has the following fundamental freedoms: freedom of thought, belief, opinion and expression, including 
The Supreme Court of Canada held that freedom of expression extends to what language one wants to express oneself in. Sometimes le mot juste (the right word) can only be found in another language. The Court thus ruled for Ford who was a discrete and insular minority of English speakers in the Province of Quebec. Quebec was furious, and it invoked its power under Section 33 of the Charter to suspend Ford v. Quebec for five years. At the end of that time, Quebec passed a new law allowing English language signs so long as they were smaller than French language signs. ${ }^{68}$ Section 33 of the Charter was not invoked again.

In Reference re Secession of Quebec, ${ }^{69}$ the Canadian national government asked the Supreme Court of Canada for an advisory opinion on what would be the legal effect if the political outsiders in Quebec passed a secession referendum, as almost happened in 1995 when such a referendum failed to pass because $50.58 \%$ of the population opposed it, while $49.42 \%$ approved of it. ${ }^{70}$ The Canadian Supreme Court said that were such a referendum to pass, the Canadian national government would have to enter into serious secession negotiations with the government of Quebec. However, Quebec could not secede with its current borders; it would have to credibly commit to protecting the rights of English speakers in Quebec Province; the national debt would have to be shared; and obligations to Aboriginal people would have to be shared. The Supreme Court's lengthy opinion totally calmed the waters, and, in retrospect, the prospects for Quebec secession appear to have peaked in 1995. The reason for this is that the Supreme Court of Canada handled its French-speaking, minority, political outsiders in a way that salved their hurt pride.

In Reference re Provincial Electoral Boundaries (Saskatchewan) ${ }^{71}$ the Canadian Supreme Court heard a one person, one vote challenge to its unequally populated electoral districts, which Canada calls "ridings." The constitutional right at issue here is Section 3 of the Charter, which provides:

\footnotetext{
freedom of the press and other media of communication.").

68. R. Hudon, Bill 86, CAN. ENCYClOPEDIA (Dec. 16, 2013), https://www.thecanadianencyclopedia.ca/en/article/bill-86.

69. [1998] 2 S.C.R. 217 (Can.).

70. CALABRESI, THE G-20 COMMON LAW COUNTRIES AND ISRAEL, supra note 2, at 216.

71. [1991] 2 S.C.R. 158 (Can.).
} 


\section{Democratic Rights of citizens}

3. Every citizen of Canada has the right to vote in an election of members of the House of Commons or of a legislative assembly and to be qualified for membership therein. ${ }^{72}$

The Canadian Supreme Court cited all of the Warren Court's one person, one vote cases, and it concluded that there were two possible ways to interpret Article 3 of the Charter. Section 3 could be read to guarantee "equality of voting power" or to guarantee "effective representation." The first model is the one the United States has followed of near absolute voter equality among districts. The second model is the one England and Canada have historically followed, which allows for what Ely calls "virtual representation." Under this model, the United Kingdom argued it could tax the thirteen North American colonies because they were "virtually represented" in Parliament, even though they had no seats in the House of Commons, because many other parts of the U.K. were in the same boat. It was disagreement over this claim that set off the American Revolution!

Justice McLachlin's opinion for the Supreme Court of Canada describes the English/Canadian model of "virtual representation" as being:

the less radical, more pragmatic approach which had developed in England and in this country through the centuries and which was actually in place....

[W]e should assume that the goal was to recognize the right affirmed in this country since the time of our first Prime Minister, Sir John A. Macdonald, to effective representation in a system which gives due weight to voter parity but admits other considerations where necessary ....

[O]ur system is rooted in the tradition of effective representation and not in the tradition of absolute or near absolute voter parity. It is this tradition that defines the general ambit of the right to vote [in Section 3 of the Charter]. This is not to suggest, however, that inequities in our voting system are to be accepted merely because they have historical precedent. History is important in so far as it suggests that the philosophy underlying the development of the right to vote in this country is the broad goal of effective representation ....

72. Canadian Charter of Rights and Freedoms, Part I of the Constitution Act, 1982, being Schedule B to the Canada Act, 1982, c 11 § 3 (U.K.). 
In the final analysis, the values and principles animating a free and democratic society are arguably best served by a definition that places effective representation at the heart of the right to vote. The concerns which Dickson C.J. in Oakes associated with a free and democratic society-respect for the inherent dignity of the human person, commitment to social justice and equality, respect for cultural and group identity, and faith in social and political institutions which enhance the participation of individuals in society - are better met by an electoral system that focuses on effective representation than by one that focuses on mathematical parity. Respect for individual dignity and social equality mandate that citizen's votes not be unduly debased or diluted. But the need to recognize cultural and group identity and to enhance the participation of individuals in the electoral process and society requires that other concerns also be accommodated.

In summary, I am satisfied that the precepts which govern the interpretation of Charter rights support the conclusion that the right to vote should be defined as guaranteeing the right to effective representation. The concept of absolute voter parity does not accord with the development of the right to vote in the Canadian context and does not permit of sufficient flexibility to meet the practical difficulties inherent in representative government in a country such as Canada. In the end, it is the broader concept of effective representation which best serves the interests of a free and democratic society $\ldots{ }^{73}$

Jeremy Webber notes that disparities in the number of voters in Canadian ridings can be quite significant: "In the 2011 General Election, the average number of registered electors per riding was 78,758. The most populous riding in Canada (in suburban Ontario) was virtually twice as large, with 153,972 electors. The least populous riding outside the territories was Labrador, with 20,305 electors; the average number of electors in the four [Prince Edward Island] ridings was 27,114." ${ }^{\prime 4}$

A helpful way for Americans to understand the Canadian system is by acknowledging that the U.S. Constitution itself opts for effective, and not mathematical, representation in the U.S. Senate and in the Electoral College, which picks U.S. presidents. We do have a one person, one vote rule for House of Representative districts and state legislative districts, but we

73. Id. at $186-89$.

74. Jeremy Webber, The Constitution of CANAdA: A Contextual ANALYSIS 83 (2015). 
depart from one person, one vote with the Senate and the Electoral College. I am not bothered by this U.S. departure from one person, one vote, and actively favor it, because I think very important federalism concerns are satisfied in this way in the United States. Canada's Senate is not coequal to its lower House, and Canada has no Electoral College. Deviations from one person, one vote thus work to over-represent Northern Canadian rural interest groups (as does the U.S. Senate and the Electoral College in the U.S.), and it disproportionally benefits Aboriginal peoples.

Canada's rejection of Ely's one person, one vote Warren Court theory should also be taken with a grain of salt given the acceptance of one person, one vote in populous global powerhouse countries with strong militaries and/or big economies like the United States, Germany, and Japan. It should be mentioned here that Canada's population of 38 million people ${ }^{75}$ is smaller than California's population of 39.5 million residents, ${ }^{76}$ the Canadian military is almost non-existent, Canada has only the tenth largest economy in the world ${ }^{77}$ and Canada ranks 99 out of one hundred as being the least population-dense country in the world. Ninety percent of Canadians live within 100 miles of the U.S. border, and the question of how to represent the vast, cold, rural North of Canada is truly unique to Canada alone. Prime Minister Justin Trudeau won a plurality of seats in the House of Commons, and thus has total economic and legislative control over all non-judicial matters, after winning only $32.6 \%$ of the vote nationwide, a record for the lowest percent of the national government gained by the plurality winner of a federal election. ${ }^{78}$ This is not an electoral system that any other country should want to emulate.

A second umpiring of the political process opinion of the Supreme Court of Canada, which is of interest given Democracy and Distrust, is the Canadian campaign finance decision in Harper

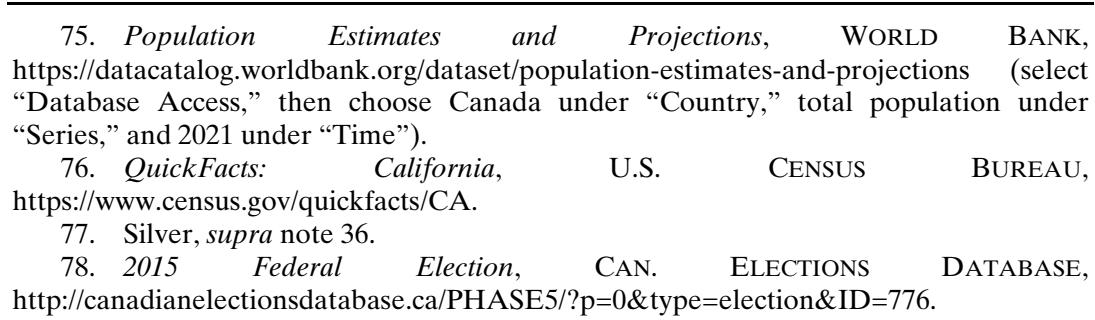


v. Canada (Attorney General).$^{79}$ In this case, the Supreme Court of Canada accepted broad limits on campaign spending that would violate the U.S. rules in Buckley v. Valeo ${ }^{80}$ and in Citizens United v. Federal Election Commission. ${ }^{81}$ Canada is plainly a more communitarian and less Lockean country than is the United States. It has been so from the beginning. Ontario was settled by 60,000 Tory American loyalists who did not want to leave their King and country. ${ }^{82}$

\section{THE COMMONWEALTH OF AUSTRALIA}

The Commonwealth of Australia began to form in the 1890s when delegates from each of Australia's then independent six states met in conventions and agreed that they wanted to ask the U.K. to set up a federal government of Australia and to give that government Dominion status just like Canada. The delegates of the six states debated at length among themselves to produce a text, and they then negotiated with the British to make the text acceptable to the U.K. The British Parliament ultimately adopted the Australian Constitution Act, $1901,{ }^{83}$ which was submitted for ratification by referendum in each of Australia's six states. Australia's constitution was much more democratically legitimated than the British North America Act, 1867, which Canadians never voted on either in their provincial legislature or by referendum. Australia's Constitution is also better legitimated than is the Constitution of India, 1950, which was ratified only by a constitutional convention elected under U.K. voting rules. We the People of India never voted in referenda, in the Indian States, or, by specially elected state constitutional conventions, to ratify the Constitution of India. Like Canada, Australia became independent of the British Empire due to the enactment of the the Statute of Westminster, $1931 .^{84}$

Australia has a federal government, and six separate state governments. The Australian Constitution enumerates the

79. [2000] 2 S.C.R. 764 (Can.).

80. 424 U.S. 1 (1976).

81. 558 U.S. 310 (2010). 190.

82. CALABREsi, THE G-20 COMmOn LAw COUNTRIES AND ISRAEL, supra note 2 , at

83. Commonwealth of Australia Act, 1900 (Imp), 63 \& 64 Victoria, c. 12, § 9 (U.K.).

84. Statute of Westminster, 1931, 22 \& 23 Geo. 5, c. 4 (U.K.); see also text accompanying note 46 . 
powers of the national government, but not of the states. There is a Tenth Amendment analogue in the Australian Constitution ${ }^{85}$ leaving residual power with the states and the people but that residual power states merely a truism that all powers not delegated are retained, as in the U.S. Australia's attempt to reserve state powers has been just as unsuccessful as has been the Tenth Amendment. The framers of the Australian Constitution borrowed from the U.S. Constitution, the British North America Act, 1867, and from the United Kingdom's unwritten constitution.

The High Court has engaged in active federalism umpiring including in the Marbury v. Madison equivalent in Australia, which is Amalgamated Society of Engineers v. Adelaide Steamship Co. Ltd (Engineers Case) ${ }^{86}$ In that case the Australian High Court adopted a very formalistic, positivist, textualist approach to constitutional interpretation much like what Justice Antonin Scalia argued for when he was on the U.S. Supreme Court. It was not until 1988 that the High Court ever consulted the extensive legislative history of the Australian Constitution Act, 1901. In Adelaide, the High Court did away with earlier doctrines of implied governmental immunities and reserved state powers. The case is similar to the U.S. Supreme Court decision in Garcia v. San Antonio Metropolitan Transit Authority, ${ }^{87}$ which overruled National League of Cities v. Usery. ${ }^{88}$ It also has elements of United States v. Darby ${ }^{89}$ in its rejection of implied state powers.

I said above that the High Court of Australia is very textualist and formalistic in its jurisprudence to date, but there is one important case, which makes an exception to formalism to provide some measure of protection to freedom of political expression in a country that has no First Amendment or Bill of Rights. In 1991, the Australian legislature enacted into law a campaign finance law that was so strict that it prevented challengers from being able to build up the name recognition to challenge incumbent legislators. The law would essentially have ended representative democracy in Australia. The High Court in Australian Capital Television Pty Ltd \& New South Wales v.

85. Australian Constitution s 107.

86. (1920) 28 CLR 129.

87. 469 U.S. $528(1985)$

88. 426 U.S. 833 (1976)

89. 312 U.S. 100 (1941). 
Commonwealth ${ }^{90}$ held that there was an implied protection of political expression in the Australian Constitution Act, 1901, which on its face set up a representative form of government. The High Court said elections would be meaningless under this campaign finance law and that it would end the representative democracy that the Australian Constitution Act, 1901 meant to create. The Court's opinion is holistic and structural in the way argued for in Charles L. Black's Structure and Relationship in Constitutional Law. ${ }^{91}$ The High Court's opinion in Australian Capital Television Pty Ltd \& New South Wales v. Commonwealth is clearly right in my view.

In McGinty v. Western Australia, ${ }^{92}$ the High Court backed off a bit from structuralism in Australian constitutional law and returned to literal textualism. The issue was whether Australia should import the one person, one vote cases of the Warren Court into Australia's constitutional law. The answer that the High Court gave was "no." Chief Justice Brennan's opinion for the High Court deserves quotation at length:

The plaintiffs submit that disparities in voting power are inconsistent with the principal of representative democracy as that principle is understood at the present time. Representative democracy ... requires that (a) every legally capable adult has the vote; and (b) each person's vote be equal to the vote of every other person.

Of course, the term "legally capable adult" assumes without defining the scope of the franchise. In this century, the age of legal adulthood has been reduced from 21 to 18 and the legal incapacity of women to vote has been removed. Aborigines, who were once constitutionally disqualified from the franchise, are no longer so disqualified. But age, sex and race are not the only qualifications that have governed an adult's right to vote. Other qualifications have related to ownership of property and education or a period of residence within the electoral district. Disqualifications still include the status of convicted criminal and mental infirmity or absence from registered address. In view of the fact that the franchise has historically expanded in scope, it is at least arguable that the qualifications of age, sex, race and property which limited the franchise in earlier times could not now be reimposed so as to deprive a citizen of the

90. (1992) 177 CLR 106.

91. Charles L. Black, Structure and Relationship In CONSTITUtional LAW (1969).

92. (1996) 186 CLR 140. 
right to vote ....

"Representative democracy" has been used as a shorthand description of the form of government prescribed by the Commonwealth Constitution in order to explain how the freedom to discuss governments and political matters is implied in the Constitution. As "the people" are to choose their elected representatives, it has been held that the people must be left free to discuss political and economic matters in order to perform their constitutional functions ....

Although the term "representative democracy" is useful to explain the text on which the implied freedom depends, the term is not to be found in either the Constitution of the Commonwealth or the Constitution of Western Australia. It is logically impermissible to treat "representative democracy" as though it were contained in the Constitution, to attribute to the term a meaning or content derived from sources extrinsic to the Constitution and then to invalidate a law for inconsistency with the meaning or content so attributed. The text of the Constitution can be illuminated by reference to representative democracy but the concept neither alters nor adds to the text....

There are hundreds of electoral systems in existence today by which a form of representative government might be achieved. Their merits must be judged by a number of different criteria which are likely to be incompatible with one another.... There can be no implication that a particular electoral system, of the many available, is required by the Constitution. There is, of course, the express requirement that whatever system is employed it must result in a direct choice by the people. That must mean direct choice by the people through those eligible to vote at elections, but beyond that the matter of electoral systems, including the size of electoral divisions, and indeed whether to have divisional representation at all is left to the parliament....

Once it is recognised, as in my view it must be, that electorates of equal numerical size are not a necessary characteristic of representative government, the plaintiffs are driven in their argument to find in the system of representative government laid down by the Constitution a requirement that there be, as nearly as practicable, electorates of equal size. But that requirement is nowhere to be found in the any express provision of the Constitution and this Court has denied ... that there is any basis for its implication. It is not to be found in the expression "directly chosen by the people" contained in [t]he Constitution]. Indeed, [the Constitution] contain[s] 
requirements which are to the contrary ....

Of course, the problems arising from malapportionment and disproportion would largely disappear if there were no electoral divisions within a State and a system of proportional representation were adopted .... But such a system may be to the detriment of the two-party system by encouraging the growth of splinter groups .... [I]t would be unwise to freeze into a constitutional requirement a particular aspect of an electoral system the attraction of which might vary at different times.... The wisdom of those who were responsible for framing our Constitution in recognising the political nature of such matters, and in leaving them to parliament, ought not to be overborne by drawing an implication which is neither apparent nor necessary .... ${ }^{93}$

Australia, like Canada, declined to write a one person, one vote standard into its constitution preferring to rely on the British tradition of virtual representation in a representative democracy for picking the lower House of its legislature. The Australian Senate, like the U.S. Senate is apportioned so that each state has an equal number of votes in the Senate, notwithstanding differences in population. The lawsuit in this case concerned the apportionment of lower house districts in the state of Western Australia. In 1993 state elections in Western Australia: "Wanneroo, had 26,580 enrolled voters, while the smallest of the rural electorates, Ashburton, had 9135 enrolled voters." 94 The High Court's opinion in McGinty v. Western Australia is strikingly similar to Chief Justice Robert's opinion in Rucho v. Common Cause. ${ }^{95}$

Australia's rejection of the John Hart Ely's one person, one vote Warren Court theory should also be taken with a grain of salt given the acceptance of one person, one vote in populous global powerhouse countries with strong militaries and/or big economies like the United States, Germany, and Japan. It should be mentioned here that Australia's population of twenty-six million people ${ }^{96}$ is smaller than Texas's population of twenty-nine million

93. Id. at $13,17-19,24,87-88,93,98-99$.

94. GeOrge Williams, SEAN Brennan \& ANDrew Lynch, Australian CONSTITUTIONAL LAW AND THEORY: COMMENTARY AND MATERIALS 684 (6th ed. 2014).

95. 139 S. Ct. 2484 (2019).

96. Population Estimates and Projections, WORLD BANK, https://datacatalog.worldbank.org/dataset/population-estimates-and-projections (select "Database Access," then choose Australia under "Country," total population under 
residents, ${ }^{97}$ the Australian military is almost non-existent, and Australia has only the thirteenth largest economy in the world..$^{98}$ Most of Australia is uninhabited and the country ranks one hundredth out of 100 nations as being the least population dense. It is again an inapposite model for populous, economically and militarily important nations like the United States, the United Kingdom, Germany, Japan, India, and Brazil. Comparing Canada and Australia to the countries just mentioned is like comparing apples to oranges.

The Australian Constitution not only lacks a freedom of expression guarantee. It also lacks a Bill of Attainder Clause. This did not prevent the High Court from issuing one of its most important decisions of all time protecting political outsiders: the six-to-one decision in a case called The Australian Communist Party v. The Commonwealth. ${ }^{99}$ The Communist Party had been banned on and off in the 1930s and 1940s. In 1949, the LiberalCountry Party ran on a platform of banning the Communist Party. The Party won the election, and it passed the Communist Party Dissolution Bill on April 27, 1950. ${ }^{100}$ The Bill claimed to be a constitutional exercise of the defense power, the express incidental power, and the executive power. It declared the Communist Party to be unlawful, confiscating without compensation its property, and it empowered the Executive to declare unlawful any affiliated bodies. Final passage occurred on October 19, 1950. Oral argument before the High Court went on for twenty-four sitting days. ${ }^{101}$

Six of the Justices held the Bill unconstitutional, although all seven thought that parliament had at least some power to legislate as to subversive activities. Unlike the challenged law, prior sedition laws had left the question of guilt to the court to be determined through criminal trials. The Bill in this case simply found as a legislative fact that the Communist Party was guilty of seditious activities. The High Court held that the Legislative Power of Parliament did not extend to deciding facts, which only

\footnotetext{
"Series," and 2021 under "Time").

97. QuickFacts: Texas, U.S. CENSUS BUREAU, https://www.census.gov/ quickfacts/TX.

98. Silver, supra note 36

99. (1951) 83 CLR 1.

100. Communist Party Dissolution Act 1950 (Cth) (Austl.).

101. George Winterton, The Significance of the Communist Party Case, 18 Melbourne U. L. ReV. 630, 649 (1992).
} 
a court can determine in a regime, which does not give judicial power to the legislature. The opinion said the U.K. Parliament or the six Australian parliaments could have passed a communist party dissolution bill because they did not have separation of powers clauses, but the Australian national legislature could not do so because it had only the legislative power, and the executive and judicial powers were textually assigned to other branches of the government. The High Court in essence read a Bill of Attainder Clause into the separation of powers provisions of the Australian Constitution Act, 1981. The government tried to pass a constitutional amendment in 1951 giving itself the power to ban the Communist Party. But that effort narrowly failed. ${ }^{102}$ All of these events occurred at exactly the same time in which Mao Ze Dong's Communist Party was coming to power in China. People in Australia, who had feared Japanese conquest during World War II, were scared to death by Communist China.

\section{THE FEDERATIVE REPUBLIC OF BRAZIL}

The foundational Marbury v. Madison case for Brazil decided by the Constitutional Court of Brazil, which is called the Supreme Federal Tribunal (STF), is Governor of Rio Grande do Sul v. National Congress. ${ }^{103}$ It concerns the issue of one person, one vote for the Federal Chamber of Deputies of the National Congress of Brazil. That Congress has an upper House called the Federal Senate to which each of the twenty-six states and the Federal District may elect three Senators who serve for eight-year terms with two-thirds of the seats being up for election at one time and the remaining one-third are up for election four years later. The Brazilian Senate, which is inspired by the U.S. Senate, equally represents the states and is not apportioned by a rule of one person, one vote.

The Federal Chamber of Deputies, which is the Brazilian equivalent to the U.S. House of Representatives, is also not apportioned according to the rule of one person, one vote, which seems quite surprising to an American. Seats in this House are filled by proportional representation for a four-year term. Seats are allocated to the States and the Federal District by population

102. DeP'T of Parliamentary Servs., Parliamentary Handbook of THE COMmonwealth of Australia: RefERENDUMS AND Plebiscites 393 (33 ed. 2014) (49.44\% for, $50.56 \%$ against).

103. Direct Action of Unconstitutionality no 815 (1996). 
except that every state is eligible for at least eight seats and no State may have more than seventy seats under the explicit text of Article 45 of the Constitution of Brazil. ${ }^{104}$ As a result, the richer and whiter States of the South and the Southeast regions, which had in $199657.7 \%$ of the national population and which produced $77.4 \%$ of Brazil's GDP, would have only $45 \%$ of the seats in the Chamber of Deputies. In other words, Brazil's Constitution tips the balance of power in the Federal Chamber of Deputies in a way that leads to minority rule.

The wealthy southern State of Rio Grande do Sul brought a constitutional complaint before the STF arguing that the Brazilian Constitution, like the German Basic Law of 1949 before it, sets up a hierarchy of norms among which equality and majority rule in a democracy like Brazil are foundational constitutional norms that trump the mere words of the constitutional text. These norms are so foundational that the Constitution makes them not open to deletion by constitutional amendment. Following the lead of the German Constitutional Court, the State of Rio Grande do Sul argued that the 1988 Brazilian Constitution contains some implicit foundational norms that can render the text of the Constitution unconstitutional. That is what Rio Grande do Sul argued the STF should do with the text of Article 45 in this case.

The STF unanimously rejected this constitutional complaint. Justice Moreira Alves said in his opinion for the Court that:

The thesis claiming there is a hierarchy between original constitutional norms, which would allow the declaration of unconstitutionality of some of them in the face of others, seems impossible within the system of a rigid Constitution .... Every original constitutional norm receives its validity from the original Constitutional Power and not from some superior norms among them ....

[In the current Constitution,] the Supreme Federal Court is responsible, essentially for safeguarding the Constitution ... which means to say that the constitutional competence is assigned to prevent the failure to follow the Constitution. The constitutional competence is not assigned to the Court to exercise the role of supervisor of the Original Constitutional Power whereby the Court might determine if the Original Constitutional Power would have violated or not natural law principles.... This violation is not a question of 
unconstitutionality, but a question of the legitimacy of the Constitution itself ... and the Supreme Court does not have the competence to solve this question, even if we admit the existence of natural law....

The entrenched clauses do not serve to sustain the thesis of the unconstitutionality of inferior constitutional norms, inasmuch as the Constitution only foresees them as limits to the Derivative Constitutional Power when it is revising or amending the Constitution ....

Therefore, the Supreme Court cannot supervise the Original Constitutional Power either in abstract or concrete cases.... The Supreme Court cannot acknowledge the direct action of unconstitutionality. The claim is legally inadmissible.

I think the STF is clearly right that structural principles of equality and majority rule in a democracy do not trump textually clear constitutional rules to the contrary. Rio Grande do Sul is asking the STF to do something equivalent to California asking the U.S. Supreme Court to hold the U.S. Senate or the Electoral College unconstitutional as a violation of one person, one vote. As a legal matter, I think what Rio Grande do Sul was asking for is preposterous, although as a policy matter it seems hugely unfair that neither the Federal Senate nor the Federal Chamber of Deputies in Brazil are apportioned according to the rule of one person, one vote.

The relevance of this case to Ely's Democracy and Distrust is that, with a huge shove from Ely, in particular, the other democracies in the world are very aware of and respectful towards the Warren Court's one person, one vote cases. So much so that litigants bring cases like the ones just discussed. Brazil has the sixth highest population of any country in the world, ${ }^{105}$ Brazil is the fifth largest country in the world, ${ }^{106}$ and it has the ninth largest economy in the world. ${ }^{107}$ Brazil encompasses $49 \%$ of the landmass of Latin America, and it is a globally emerging power. It matters that so many Brazilians care so much about one person, one vote, even though they have not been successful in getting it.

\footnotetext{
105. Most Populous Countries in the World, WORLDOMETER, https://www.worldometers.info/population/most-populous-countries/.

106. Largest Countries in the World (by Area), WORLDOMETER, https://www.worldometers.info/geography/largest-countries-in-the-world/.

107. Silver, supra note 36 .
} 


\section{THE REPUBLIC OF SOUTH AFRICA}

The South African apartheid regime, which existed from 1948 until the first non-racial general election on April 27, 1994, was a brutal totalitarian regime, which abused all fundamental human rights. The regime claimed to be a Westminster-style parliamentary government with no need for a Bill of Rights or for judicial review. When South African Blacks demanded a Bill of Rights in their Freedom Charter of $1955,{ }^{108}$ the regime reacted with hostility. After violence broke out, the apartheid government quickly imprisoned the leaders of the African National Congress Party (ANC). The ANC's leader Nelson Mandela was imprisoned for twenty-seven years for trying to overthrow the State. Prior to his imprisonment, Mandela, who was a member of the central committee of the South African Communist Party, formed the Spear of the Nation, which was the armed wing of the ANC. It launched its first attacks against government installations in 1961. ${ }^{109}$ The government labelled the group a terrorist organization.

During the Cold War period, neither the United States nor the United Kingdom wanted South Africa to become a communist country. South Africa was expelled from the Commonwealth of Nations, ${ }^{110}$ but it was otherwise tolerated. Western leaders were afraid that the ANC would ally itself with the former Soviet Union. The Soviet Union did in fact help fund the ANC during this period. ${ }^{111}$ It was only after the fall of communism that true change in South Africa became possible.

By 1983, it was becoming increasingly apparent to the Afrikaner government that it had an acute legitimacy problem that was leading to massive campaigns in Western countries that were divesting in companies that did business in South Africa. The Afrikaners made their first pathetic attempt to come to grips with this problem by adopting a Constitution in 1983, which gave a limited political voice to the country's mixed-race Colored

\footnotetext{
108. The Freedom Charter (June $25 \quad \& \quad 26, \quad 1955)$, http://www.historicalpapers.wits.ac.za/ inventories/inv_pdfo/AD1137/AD1137-Ea6-1-001jpeg.pdf (see "All Shall Enjoy Equal Human Rights!").

109. CALABRESI, THE G-20 COMMON LAW COUNTRIES AND ISRAEL, supra note 2, at 344.

110. Our History, THE COMMONWEALTH, https://thecommonwealth.org/aboutus/history\#22.

111. CALABRESI, THE G-20 COMMON LAW COUNTRIES AND ISRAEL, supra note 2, at 345.
} 
population and to its Indian population. ${ }^{112}$ This Constitution set up a Tricameral Parliament with the members of one house being picked by Whites, the members of a second house being picked by the Colored population, and the members of the third house being picked by the Indian population. The idea pursued by Prime Minister P. W. Botha was to implement power sharing among the White, Colored, and Indian populations. The right wing of the apartheid regime split off at this point and formed a conservative party, which advocated total apartheid.

Prime Minister Botha was trying to fit South Africa into a concept that might be more acceptable to the West, which was called "consociational democracy." This was a concept championed by a famous political scientist Arend Lijphart, in the 1970s and 1980s, to describe power sharing regimes in sharply divided polities like Switzerland, Belgium, and Lebanon. ${ }^{113}$ In his book on this subject, Professor Lijphart examines thirty-six democracies during the period between 1945 and 2010. Switzerland is the most successful consociational democracy of all time. The Swiss share power among German-speaking, Frenchspeaking, and Italian-speaking citizens, in a country that is partly Protestant and partly Catholic, and a country in which rural and urban voters have different interests. Aside from Switzerland, a notable Consociational democracy, in 2021, is the devolved government of Northern Ireland in which Protestants and Catholics share power under the watchful eye of the U.K. Parliament.

Professor Bruce Ackerman notes that Botha in 1983 was trying to:

[T]ap[] into a worldwide trend toward "consociationalism" in multicultural societies. Consociationalists argue that the foundational principle of "one-person, one-vote" is unsuitable for countries that include divergent cultural communities. They fear that equal suffrage allows a "winner-take-all" system that systematically suppresses discrete and insular minorities. They support constitutional structures, like multichamber parliaments, that require the numerically dominant group to engage in ongoing consensus-building before binding

112. Joseph Lelyveld, The Afrikaners are Torn Over New Constitution, N.Y. TIMES (Oct. 9, 1983), https://www.nytimes.com/1983/10/09/world/the-afrikaners-are-torn-overnew-constitution.html.

113. See e.g, AREND LiJPHART, PATtERnS OF DEMOCRACY: GOVERNMENT Forms AND PERFORMANCE IN THIRTY-SIX COUNTRIES (2d ed. 2012). 
legislation is enacted. In calling for consociational democracy, rather than the "one person, one vote" version, Botha's vision was well within the mainline Western thinking of the era. ${ }^{114}$

Botha's 1983 Constitution, however, did not provide any power at all for Black South Africans who account for $80 \%$ of the South African population, and it only gave the vote to $20 \%$ of the population. It thus "fell far short of the consociational ideal."115 Botha held a referendum among White voters in 1983 on whether to adopt the Tricameral Parliament, and, despite heated opposition, $66.3 \%$ voted "yes." 116 The proposed constitution was ratified by the apartheid Parliament - an indication that there was some recognition among Whites that the pure apartheid regime was unacceptable. The ANC quite rightly denounced the whole thing as a sham, and the ANC called on White, Colored, and Indian voters to boycott the 1984 elections to the Tricameral Parliament. As a result, there was only a $16.2 \%$ turnout among some communities. The only important thing that the Tricameral Parliament did was to ratify the Interim Parliament in 1993, which paved the way for the first non-racial elections on April 27, 1994, and the writing of South Africa's Constitution.

Botha began secret negotiations with Nelson Mandela who was still in prison, and the Spear of the Nation kept up its bolder and bolder violent attacks on the government and its facilities. Botha resigned in 1989 after suffering a stroke, and, just as importantly, the Berlin Wall fell in 1989 marking the end of the Cold War. F. W. de Klerk, who succeeded Botha, was expected to continue the apartheid regime, but he ended it instead, realizing that any other path would lead to a bloodbath civil war. De Klerk permitted anti-apartheid marches to take place, and he released Nelson Mandela from prison, as well as dismantling South Africa's nuclear weapons program.

The United States and the United Kingdom were by the late 1980s demanding fundamental change in South Africa, and the bankrupt Soviet Union was no longer able to fund the Spear of the Nation and the ANC. The time was right for fundamental

114. BRUCE ACKERMAN, REVOLUTIONARY CONSTITUTIONS: CHARISMATIC LEADERSHIP AND THE RULE OF LAW 83 (2019).

115. Id.

116. South Africa, November 2, 1983: Constitution, DATABASE \& SEARCH ENGINE FOR DIRECT DEMOCRACY (Jan. 9, 2019), https:/www.sudd.ch/event.php? lang=en\&id=za011983. 
change, but huge obstacles lay in the way. De Klerk and Mandela came to an agreement that there should be a Bill of Rights and judicial review, which the ANC had called for in the Freedom Charter of 1955, the virtues of which were becoming more visible to White South Africans every day. The main sticking point, however, was that de Klerk kept lobbying for a consociational democracy in which Blacks would share power with Whites, while Nelson Mandela and the ANC insisted on universal suffrage and one person, one vote.

In the end, de Klerk was forced to back down. The idea of universal suffrage and of one person, one vote had triumphed. This showed the international appeal of Ely's norm and the Warren Court's norm, which in South Africa was realized through a process of negotiation and with no need for a court! Mandela and de Klerk set up an interim government with an entrenched Bill of Rights that protected property rights. The interim government would simultaneously govern the nation as a parliament and serve as a constitutional convention. The two sides agreed that in April 1994 a non-racial Parliament would be elected for the first time with universal suffrage and one person, one vote. The Constitutional Court would then judicially review the proposed constitution to make sure that it satisfied thirty-four basic principles. ${ }^{117}$ "During the two-year period 1994-1996, a massive public education campaign was conducted relating to the drafting of the Constitution, including circulating drafts of various provisions and seeking public input."118

From 1994 to 1996, Nelson Mandela served as the new President of South Africa with the ANC's Thabo Mbeki and F. W. de Klerk serving as Deputy Presidents under an Interim Constitution. "The procedures agreed to in the earlier negotiations and embodied in the Interim Constitution required that the new Constitution be passed by a two-thirds vote of the legislature and then be reviewed by the Constitutional Court, to determine whether the new Constitution fully complied with the 34 basic principles." 119 In May 1996, the legislature ratified the Constitution by an $86 \%$ majority and certified it to the

117. ViCKI C. JACKSON \& MARK TUSHNET, COMPARATIVE CONSTITUTIONALl LAW at 283 (2d ed. 2006).

118. Id.

119. Id. 
Constitutional Court for review. ${ }^{120}$ On June 20, 1996, de Klerk's position as Deputy President came to an end. In early September, the Constitutional Court approved the Constitution but found that "in 9 respects the draft Constitution did not sufficiently comply with the 34 principles." " Among the complaints was that the power of two-thirds of both Houses of the legislature to amend the Bill of Rights was insufficiently protective of minority rights. Parliament made "about 40 revisions to address the Court's objections." 122 The Constitutional Court "approved the new draft in late 1996," and "President Nelson Mandela issued a proclamation by which the Constitution was to come into effect beginning in February, 1997." 123

This use of judicial review in the writing of a new Constitution, so as to make sure it adequately protects "discrete and insular minorities and political outsiders" is unprecedented. It also conforms totally to Ely's theory of judicial review in Democracy and Distrust. It is hard to imagine a bigger victory for Ely's ideas than the South African case described above. The experience in South Africa matters globally because South Africa has the second largest economy in Africa after Nigeria's, which is striking because South Africa has a population of only sixty million people ${ }^{124}$ compared with Nigeria's population of over 211 million. ${ }^{125}$ South Africa is a global leader and an emerging strong economic leader. And, it practices the rule of one person, one vote.

120. Id. at $283-84$.

121. Id. at 284 (citing In re Certification of the Constitution of the R.S.A, 1996 (4) S.A. 744 (Constitutional Court Sept. 6, 1996 (South Africa)).

122. Id.

123. Id. at 285; see also In re Certification of the Amended Test of the Constitution of the R.S.A, 1996, (2) S. A. 97 (Constitutional Court Dec. 4, 1996).

124. Population Estimates and Projections, WORLD BANK, https://datacatalog.worldbank.org/dataset/population-estimates-and-projections (select "Database Access," then choose South Africa under "Country," total population under "Series," and 2021 under "Time").

125. Id. (select "Database Access," then choose Nigeria under "Country," total population under "Series," and 2021 under "Time"). 


\section{CONCLUSION}

The first conclusion I draw from studying these nine countries is that the one person, one vote decisions in the U.S. were essential to offset the Senate and the Electoral College, while the over-representation of rural voters in Canada and Japan may make some sense in those countries given that neither country has an equivalent to the U.S. Senate and Electoral College. A similar phenomenon may be at work in Australia given its sparse population and ultra-low population density even though Australia does have a powerful Senate in which its states are equally represented.

My overall conclusion is that I think Ely was right to call on the courts to police the political process to let outsiders in. I think our one person one vote rule for the House of Representatives and Germany's similar role for its lower House of Parliament are desirable, and I think the United Kingdom, Canadian, and Australian idea of "virtual representation" is loony. I think the U.S. Supreme Court should decide gerrymandering cases, and it should overrule Rucho v. Common Cause and Shelby County v. Holder, although I do not expect that to happen anytime soon. New democracies, if any emerge, should have at least half of their legislatures chosen by a one person, one vote rule with the other half representing regions.

The second conclusion I draw from studying these cases, and especially from studying the U.S. cases since Ely's book was published in 1980, is how partisan the courts are when it comes to umpiring the political pathways of change. As Ely said of the substantive due process cases, which he despised, they "have the smell of the lamp about them." ${ }^{126}$ Courts are by their nature elitist, oligarchic institutions, a fact we cannot change simply by changing their docket. Finally, this Paper could easily be five times as long as it is now if I counted every Elyan case I know of from the fifteen G-20 Nations, which are constitutional democracies and which I have studied. Ely is right as a positive matter that cases will come up all the time in Supreme and in Constitutional Courts as to whether the processes of political change are working well for political outsiders.

126. JOHN HART Ely, DEMOCRACY AND Distrust: A THEORY OF JUdicial REVIEW 59 (1980). 
